\title{
Is our Economy's Financial Sector Worth What it Costs Us?
}

\section{Citation}

Friedman, Benjamin M. 2013. "Is Our Economy's Financial Sector Worth What It Costs Us?." In proceedings of the 14th Annual International Banking Conference, Federal Reserve Bank of Chicago, Chicago, IL, November 10-11, 2011: In The Role of Central Banks in Financial Stability: How Has It Changed?, edited by Douglas Evanoff, Cornelia Holthausen, George Kaufmann, and Manfred Kremer. Hackensack: World Scientific.

\section{Published Version}

http://www.worldscientific.com/worldscibooks/10.1142/8720

\section{Permanent link}

http://nrs.harvard.edu/urn-3:HUL.InstRepos:17936783

\section{Terms of Use}

This article was downloaded from Harvard University's DASH repository, and is made available under the terms and conditions applicable to Open Access Policy Articles, as set forth at http:// nrs.harvard.edu/urn-3:HUL.InstRepos:dash.current.terms-of-use\#OAP

\section{Share Your Story}

The Harvard community has made this article openly available.

Please share how this access benefits you. Submit a story.

Accessibility 
FRB of Chicago Conference Panel November 11, 2011

\title{
IS OUR ECONOMY'S FINANCIAL SECTOR WORTH WHAT IT COSTS US?
}

\author{
Benjamin M. Friedman \\ William Joseph Maier Professor of Political Economy \\ Harvard University
}

In 1867, when the American economy was still largely agricultural, Horace Greeley, the editor of the New York Tribune, threw out the following challenge in a lecture that he gave in lower Manhattan: "There are 500,000 farmers, probably, in the state of New York to-day, who, if you were to ask each of them how much per bushel his corn had cost him to grow for the last twenty years, I doubt if fifty of the 500,000 could tell you. And this is but one instance out of ten thousand. Now, every grower of agricultural products should inquire and ascertain, year after year, 'What does this cost me? What does it bring me ${ }^{\prime \prime}{ }^{\prime 1}$

In the United States we no longer live in an 
agricultural economy. Today we have mostly a service economy, and much of our production of services takes place in the financial sector. Especially in the wake of the recent financial crisis, I think it is important for us to ask ourselves the "Greeley question" - but directed toward our modern financial sector: Do we know what our economy's financial sector is costing us? And do we have a sense of what we are getting for what we pay?

The essential function of the financial sector in a free enterprise, capitalist economy is to allocate the economy's scarce capital investment. In aggregate, the American economy typically invests about one-fifth of what it produces. No central authority makes that so. This determination is made by the financial sector, as is the allocation across countless diverse investment applications, in both instances in a highly decentralized way. The financial sector serves other functions as well, of course, including operating the economy's payments mechanism, providing liquid savings vehicles for individuals, enabling families to save for retirement, and providing insurance of a variety of forms. But there exist successful public utility models for each of those other functions. The one function that is essential to the private financial sector in a capitalist economy is

$$
\begin{gathered}
\text { Victoria's Transcription Services, Inc. } \\
\text { (312) 551-8818 }
\end{gathered}
$$


allocating the investment of the economy's capital stock.

The fact that this is the financial sector's essential function suggests a logical benchmark for at least beginning to measure what it costs to run: the share of the total return to the economy's invested capital that is dissipated in the process of allocating that capital. The element of this cost that has attracted the most widespread interest in recent years, as several of the comments at this morning's panel illustrated, is the total profits accruing to the financial sector. As is by now well known, the share of total profits in the U.S. economy earned by firms in the economy's financial sector rose from ten percent, on average from the 1950s through the 1980s, to above twenty percent in the 1990s, and then above thirty percent in the 2000 s until the crisis. Given the large increase, it is no surprise that these profits have attracted attention.

But the profits earned by financial firms are only one element, and presumably a small element, of the all-in cost of running the economy's financial sector. There are personnel costs, in the form of salaries, benefits and bonuses. There are real estate costs, including office rentals and rental equivalents for owner-occupied buildings. There are utility bills associated with heating Victoria's Transcription Services, Inc. (312) 551-8818 
and cooling these premises, there are travel budgets, there are advertising budgets, and the list goes on.

Importantly, referring again to the allocation of the economy's resources, each of these costs is a reflection of real resources absorbed. I teach in a university, and so the aspect of these costs that I see in action on a regular basis is the attraction of so many of our graduates into this line of work. Approximately a quarter of the graduates at my university go into the financial sector. Arguably, both at my university and at others too, those who choose to do so include many of our brightest, most energetic and most highly motivated young people. They could be doing something else. In light of the compensation that they receive, at an individual level no one can question their decision to choose financial sector careers. At the aggregate level, maybe it is true that their combined talents are actually necessary for allocating our economy's capital stock. If so, then this valuable human resource is an important element in what the economy pays to carry out this function.

Similarly, if we walk outside the door of this Federal Reserve Bank, or in New York we take a walk up Park Avenue just north of Grand Central Station, we can observe that the use to which our economy puts the choicest real estate

$$
\begin{gathered}
\text { Victoria's Transcription Services, Inc. } \\
\text { (312) 551-8818 }
\end{gathered}
$$


in almost every one of America's major cities is likewise the allocation of its capital investment. Here too, maybe our way of allocating the capital stock cannot function without taking up so much of our prime urban real estate. If so, this resource too is another element in what makes carrying out this key function as we do so expensive.

A different kind of element in this cost, one that we cannot measure directly but that as economists we have ready conceptual means of calculating, is the exposure of our economy to damaging volatility of the form that we have only just experienced in the aftermath of the recent financial crisis. From an economic perspective, the logical approach to assessing this cost is to ask how much of each year's national income we would be willing to pay to buy insurance against such volatility -- if that insurance were provided by the market, which of course it is not. Given that it is not, so that we therefore live with the volatility to which our way of allocating the economy's capital subjects us, the shadow price that we would pay for insuring against it is also an element in what this allocation mechanism costs us. Assessing the benefits that our capital allocation mechanism delivers is conceptually more difficult. The reason is that there is no obvious benchmark for purposes 
of comparison. We are all aware that the American economy has had a pretty good record of dynamic growth over a very long period of time. It is difficult to imagine firms like Google, or Microsoft, or Apple, having been created in most other economies. It is clear that our financial system has historically played a key role in making this happen. More recently, however, there is ample room to question how well our capital allocation mechanism is performing. Once again, the fundamental issue is resource allocation. In the wake of the most recent crisis, much of the public conversation was about the losses that firms took on their holdings of mortgage-backed securities, and correspondingly about the difficulties facing households that were (and in many cases still are) under water on their home mortgages. But the important point is that the losses incurred on these securities means that their price was too high to begin with; and because the price of the securities was too high, the rate paid on the underlying mortgages was too low - with the result that Americans built and bought, and now own, millions of houses that nobody wants. Building those houses was a misuse of the labor and capital resources that went into them.

Nor is the most recent experience unique. When the "dot-com bubble" burst, at the end of the 1990s, the

$$
\begin{gathered}
\text { Victoria's Transcription Services, Inc. } \\
\text { (312) 551-8818 }
\end{gathered}
$$


public's attention mostly focused on the losses that investors took on their telecom stocks. But once again those losses were merely the surface reflection of a misallocation of the economy's labor and capital resources. The fact that investors took a loss on their telecom holdings means that the price of the securities was too high to begin with - which in turn means that the cost of capital to the firms that issued them was too low, and as a result these firms laid hundreds of millions of miles of fiber optic cable that were never lit.

To repeat, we have no convenient conceptual benchmark for comparing how well our economy's capital allocation mechanism is performing relative to something else. We all know that capital allocation by central planning has been totally discredited - and appropriately so. But this is not an excuse for shying away from questioning the specifics of the capital allocation mechanism that we have. By analogy, it may be worth remembering the concerns that many people expressed a quarter-century or so ago, during the Cold War era, about some European countries' politics (not surprisingly, including many of the countries that are experiencing economic trouble today). At that time even the supporters of the then-dominant center-right parties in these countries readily acknowledged their sclerotic 
character, empty programs and corrupt office holders. But, so the argument went, there was no alternative - because the only alternative was the Communists, and that was no alterative at all. This is not a thought process we should aspire to repeat.

I have no candidate measure to suggest for benchmarking at the aggregate level the benefits we receive from our economy's quite expensive capital allocation mechanism, although I am optimistic that someone will be able to solve this conceptual problem. But I can also imagine tackling this question on a piecemeal basis - that is, by asking what benefit we get from any given component of our capital allocation mechanism. What would be different, for example, if we did not have the high-speed trading firms whose activity now constitutes well over half of the volume on the New York Stock Exchange? Would we end up allocating our economy's capital stock less efficiently? If so, by how much?

Or, to take some examples closer to the causes of the recent crisis, what would be different if we did not have a market for $\mathrm{CDS}^{\prime} \mathrm{s}$, or $\mathrm{CDO}^{\prime} \mathrm{s}$, or CDO-squared's? More generally, what would be different if we did not have securitization of mortgages at all? An often repeated theme in today's public discussion is that it is now

$$
\begin{gathered}
\text { Victoria's Transcription Services, Inc. } \\
\text { (312) 551-8818 }
\end{gathered}
$$


impossible to go back to a world in which mortgages were not securitized. An uninformed visitor, considering the matter from the fundamental perspective of resource allocation, might suppose this means that in the era before mortgage securitization it was impossible for Americans to build and buy houses. But of course that was not so. Americans did build and buy houses, and own them and live in them, in a world in which there was no securitization. Indeed, the American rate of home ownership was the world's highest long before anyone thought to securitize the first home mortgage.

I propose that the economics profession, including the Federal Reserve System and other key elements of our government's statistical apparatus, ought to play a leading role in undertaking a serious research effort along the lines I have suggested. We should initiate a major project aimed both at measuring the all-in cost of what it takes to run our economy's capital allocation mechanism and, much more difficult because of the conceptual challenge that I have described, at estimating the benefit we get out of it. Let me close with an analogy that Horace Greeley's agriculturally grounded listeners would have understood. If a new fertilizer offers a farmer the prospect of a higher yield on his land, it is only common sense that the

$$
\begin{gathered}
\text { Victoria's Transcription Services, Inc. } \\
\text { (312) 551-8818 }
\end{gathered}
$$


farmer should compare the incremental economic return from the enhanced harvest to the cost of achieving it. If what it costs him to buy this new fertilizer, and to transport it to his farm and spread it on his fields, exceeds the sale price of the additional crops it would enable him to produce, that makes it a poor investment for the farmer despite the fact that it does yield additional technical efficiency

The system that allocates our economy's capital stock is no different. Even if it allocates the economy's capital more efficiently than some alternative, if it costs more to run than the incremental return that the superior allocation produces then it's only so much overpriced manure.

1 Horace Greeley, "Success in Business." Address delivered before the students of Packard's Bryant \& Stratton New York Business College, November 11, 1867 (New York: S.S. Packard, 1867), p. 27. 